\title{
Split threatens young scientists' group
}

Washington. A highly public feud between founder members of the Young Scientists' Network (YSN) and some of its more radical participants is threatening to split the body responsible for a pioneering computer bulletin board which has served as an important focal point for young researchers facing cut-throat competition for research posts.

Relations between the two factions have worsened since the first group inadvertently chose 19 April - the day of the Oklahoma bombing - to accuse the second of 'infoterrorism' in distributing leaflets to high school students attending a meeting on 13 April at the University of Texas at Dallas carrying information about the difficulty researchers face finding jobs.

Some prominent members of the network, including Kevin Aylesworth, who founded YSN in 1990 and has since become active in science policy circles in Washing- ton, are now considering setting up a formal organization to represent young scientists on a far broader front.

Aylesworth and his allies believe that the issue which the network once addressed that young people were being misled into thinking there was a shortage of scientists, while in fact the United States was producing a glut of $\mathrm{PhDs}$ - has now been resolved. They now favour a shift of emphasis towards defending science from impending Congressional cuts.

On 28 April, a message was posted on the bulletin board signed by Aylesworth, John Sahr and John Quakenbush - both administrators of YSN - and five others, saying that "the war of 'the Myth' [of a scientist shortage] has, to a large extent, been won." It called on YSN members to mobilize instead against Congressional cuts.

But the proposal to redirect the activities

\section{Director quits over A-bomb exhibit}

Washington. Martin Harwit, the director of the National Air and Space Museum (NASM) in Washington DC has resigned, three months after the Smithsonian Institution abruptly cancelled a controversial exhibition there intended to commemorate the fiftieth anniversary of the dropping of the atomic bomb and the end of the Second World War.

The NASM is one of several museums and galleries in Washington that come under the aegis of the Smithsonian. Harwit's departure had long been sought by the Air Force Association and other crit-

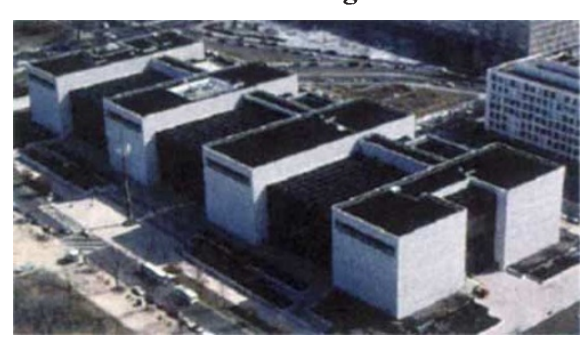

Under siege: National Air and Space Museum. lion visitors last year, is the most popular in the United States. "I had to decide whether staying on was helpful or detrimental to the museum," he says. "I am happy that the controversy will die now. People will be satisfied, and the museum will be able to take a new direction."

But some of Harwit's former colleagues still at the museum are somewhat less sanguine. "We're in limbo," says one of Harwit's former colleagues. "We don't know what our new direction will be, or what our mandate will be." A colleague at the ics of the cancelled exhibition, which was to have used as a focus the aircraft that dropped the bomb, Enola Gay.

But according to both staff and outside observers, it leaves curators at the embattled institution more anxious than ever about its ability to maintain its integrity in the face of external political pressure.

"The curators are terribly discouraged and demoralized," says Stanley Goldberg, a consultant to the Smithsonian and a leading historian of science, who served on the advisory board of the exhibition. "The question is whether scholars can do their work without having to make sure that it agrees with the prejudices of outsiders looking over their shoulders".

Harwit, an astrophysicist, claims that his departure is in the best interests of the museum which, with more than 8 mil- museum adds: "The situation is clearly very bad, and the resignation is just the latest chapter. It is a victory for our most unreasoned critics."

These critics can expect a field day today - 11 May - when they testify before the powerful Senate Rules committee, chaired by Ted Stevens (Republican, Alaska), at a hearing on the performance of the Smithsonian.

In a statement issued after Harwit's resignation, Michael Heyman, the institution's secretary, praised his director's eight-year record. But the statement said little about the Enola Gay fracas, and Heyman declined to comment further. Asked if Heyman was the right man to lead the Smithsonian at this time, Harwit said that after six months, it is "much too early to judge".

C.M. of the network drew scorn from some of the 3,000 young scientists who subscribe to it. Early response to the posting was largely negative. "A few national magazine and newspaper articles in a four year period do not a war win," wrote Ray Greene from Cornell University, New York.

The main point at issue between the two groups appears to be whether the YSN has, in fact, met its original objective by effectively dispelling the so-called myth of a scientistshortage. Aylesworth says that it has. Today, he says, "no-one on Capitol Hill believes that there is a scientist shortage".

Others on YSN — such as Gene Nelson, an unemployed biophysics $\mathrm{PhD}$ living in Dallas who did the leafleting at the Texas meeting, which was addressed by Nobel Laureate Francis Crick - think the myth is alive and kicking among the general public. In a recent posting, Nelson drew a parallel between young people going into the performing arts and science. "My strong advice now is, don't give up the day job," he wrote.

Supporters of Nelson point out that he was merely distributing publicly-available information to high-school students, who should be old enough to assess it before making career decisions. But his opponents think that advising school children to avoid science is irresponsible, and that support for such an approach will alienate official science lobbying groups such as the American Physical Society (APS) with which young scientists need to work.

The core of the dispute appears to be whether the young scientists ultimately share the same interests as their older colleagues. Aylesworth thinks they do. There is now "a pretty big gulf" inside YSN, Aylesworth says. "Eventually, some new organization may emerge."

For Nelson, the network exists to snap at the heels of APS and other bodies - not join them at the tables of power. He says there is no need to split. "The last thing the YSN needs in these perilous times is to splinter apart," he says. Colin Macilwain

\section{Clean-up funds cut}

Washington. The US Department of Energy, Washington State and the Environmental Protection Agency have agreed $\$ 1$ billion of cuts in the clean-up programme at Hanford, the United States' most problematic nuclear site, over the next two years.

Tom Grumbly, assistant energy secretary, said last week that the cuts, which represent one-quarter of the Hanford clean-up budget, would come from competitive tendering and reduced overheads and paperwork. But with the threat of even deeper cuts from Congress, environmentalists are worried that the already glacial progress on clean-up at Hanford may come to a halt.

C.M. 